\title{
Macroscopic and microscopic studies of the nests and the stages involved in the nesting process of Centris muralis Burmeister (Hymenoptera: Apidae: Centridini) bee in the adobe walls, in La Rioja, Argentina
}

\author{
Gabriela Cilla $^{1}$ \& Guillermo RolóN ${ }^{2}$ \\ ${ }^{1}$ División Entomología, Museo Argentino de Ciencias Naturales, Av. Ángel Gallardo 470, (C1405DJR) Ciudad de Buenos \\ Aires, Argentina; e-mail: cillagabriela@gmail.com \\ ${ }^{2}$ Instituto de Arte Americano e Investigaciones Estéticas, Facultad de Arquitectura Diseño y Urbanismo, Pabellón III, \\ Ciudad Universitaria, (C1428EHA) Ciudad de Buenos Aires, Argentina; e-mail: grolon@fadu.uba.ar
}

\begin{abstract}
Centris (Wagenknechtia) muralis Burmeister is one of the most common bee species distributed in the xeric region of Argentina. This work describes macro-and micromorphological aspects of the nesting architecture and the stages involved in the process of nesting of C. muralis bee, in the adobe walls of Capayán ruins and recent earthen constructions in Udpinango and Villa Castelli, La Rioja, Argentina. In addition, we discuss the possible factors that may explain the high density of nests observed in the adobe walls of Capayán ruins. These constructions are settled in the northern area of the Monte desert. Our analysis showed that the nest cell walls are strengthened and waterproofed probably by the admixture of organic material to the adobe matrix. Light microscopy of thin sections of the vacated cells showed the inner layers of organic material corresponding to the cocoon, and the outer layer of $0.7 \mathrm{~mm}$ thick corresponding to the cell walls consisting mainly of silt and clay, fine sand grains in low rate and absence of grains of sand medium and large. The cell wall was not different in its granulometry from that in the adobe brick, thus suggesting that the cell wall was constructed probably by cementing the particles with bee secretion. The scanning micrographs showed that the cell walls and non-nesting zones exhibited abundant clay crystals in the grain distribution. Pollen from Larrea sp. was observed in high proportions in the nest contents of $C$. muralis in the Capayán adobe walls.
\end{abstract}

Key words: Larrea sp.; morphological aspects; nesting activity; semidesertic zone; solitary bees

\section{Introduction}

Centris is a primarly tropical genus consisting of 150 species (distributed among 12 sugbenera) of the tribe Centridini (Michener 2007). Members of the genus Centris are especially important because of their abundance and foraging behavior efficiency (Quiroz-Garcia et al. 2001, 2006). Thirty-two species of Centris have been recorded for Argentina (Roig Alsina 2000), including the phytogeographic region of Monte. This area has a rich fauna of Centris, particularly of the subgenera Wagenknechtia, Penthemisia and Paracentris, groups mainly associated with arid conditions.

The nesting habits for the genus Centris were reviewed by Coville et al. (1983) and Frankie et al. (1983, $1988,1993)$. Species of most of the 12 subgenera of Centris excavate nests in the soil, either in flat ground, in banks or mounds (Coville et al. 1983; Rozen \& Buchmann 1990; Camillo et al. 1993; Aguiar \& Gaglianone 2003; Ręgo et al. 2006; Sarzetti \& Genise 2011), but some species nest in preexisting burrows in old wood, the soil, or other substrates (Michener \& Lange 1958; Coville et al. 1983; Snelling 1984; Roubik 1989; Jesus
\& Garófalo 2000; Aguiar \& Garófalo 2004; Mendes \& Ręgo 2007; Vinson et al. 2010). Species of subgenus Ptilotopus make nests in termitaria of Nasutitermes, often in trees (Gaglianone 2001; Ramos et al. 2007). In most Centridini, nest cells are in irregular clumps or isolated and not in distinct series. The cell walls of ground-nesting centridines are not generally separable from the substrate and are often strengthened and rendered waterproof by the admixture of resin or other materials, including floral oils from Malpighiaceae (Hiller \& Wittmann 1994; Michener 2007) and probably from Krameriaceae, Scrophulariaceae and Iridaceae (Neff \& Simpson 1981). Oil collecting behavior has been documented for many species of Centris. The presence of basitarsal combs of specialized setae, flattened blunt bristles on the anterior margin of both front and middle basitarsi, is involved in the collection of the floral oils. Centris species carry the floral oils as larval food, and part of this oil is applied on the nest walls (Neff $\&$ Simpson 1981). The structure and position of the oil collecting organs is correlated with the type of floral oil glands (elaiophores) utilized by different species of Centris. Variations of the typical Centris comb pattern 
(Vogel 1974), as well as reduction or absence of combs has occurred in the genus. This reduction or absence of combs is found in several groups of desert Centris in both North and South America (Neff \& Simpson 1981). Extreme reduction of the combs is found in some species of the subgenus Paracentris (the taxa formely assigned to subgenus Xerocentris, see Zanella 2002) of the Sonoran desert and of central and southern California, North America. The northern distribution range of this subgenus in central California extends well beyong the areas where the plants producing floral oils are scarce. In the southern portion of this range, where species of the subgenus are sympatric with oil-producing plant taxa, extensive observations indicate that some North American Paracentris do not visit oil flowers. This loss of the oil-collecting habits in deserts may be related to the possible role of oils in controlling hygroscopic effects among bees nesting in extremely moist environments, as part of the nest lining preventing the mold proliferation or bacterial attack (Neff \& Simpson 1981). Centris (Paracentris) pallida Fox, 1899, in the Sonora Desert, makes cells of compacted soil that are not waterproofed with resin or oil, but, as in all species of the Centris, are lined with a thin, shiny secretion lining (Rozen \& Buchmann 1990; Michener 2007). The nature of the hardening substance is unknown but might bee either a glandular secretion or material brought into the nest such Cercidium nectar. A less extreme reduction of basitarsal combs is found in C. (Penthemisia) mixta Friese, 1904 a species found in the deserts of coastal Perú and northern Chile, and in the group of taxa allied. This species has lost the oil collecting habits and makes cells of compacted soil particles, similar to those of C. pallida, presumably held together by a secretion of the bee (Chiappa \& Toro 1994).

The robust, hairy bee Centris (Wagenknechtia) muralis Burmeister, 1876 is a common bee species distributed in the xeric region of Argentina, including the Monte and Espinal (Roig Alsina 2000). In the considerations of the distribution patterns of the bee fauna and associated flora present in this region, Michelette \& Camargo (2000) associated Centris muralis activity with the spring bloom of Larrea spp. and Bulnesia retama. These plants provide a source of wildflowers on which the local apifauna feed. The early works by Jörgensen (1909, 1912a, b) included some descriptions about the nesting and foraging activity of $C$. muralis in the xeric western zones of Argentina. This author observed that this species nested in colonies in adobe walls, rarely in earthen banks, from October to December, and recorded plant hosts from the observation of flower visits. Sarzzeti \& Genise (2011) reports the alternative use of soil mounds as a nesting site by $C$. $m u$ ralis. Oil-producing plant species are abundant in the range of distribution of $C$. muralis, and species such as Tricomaria usillo (Malpighiaceae) are highly visited by other species of Centris, such as C. brethesi Schrottky, 1902 and $C$. tricolor Friese, 1900, but C. muralis does not visit this set of oil flowers (Jörgensen 1909; Neff \& Simpson 1981). In addition, structural differences in the basitarsal combs of $C$. muralis from those of species known to collect oils suggest the probable loss of oil collecting habits in this species (Neff \& Simpson 1981).

The effects of the nesting of $C$. muralis were early observed in the earthen walls of houses of the villages in the Patagonian region by Burmeister (1876), and in the earthen walls of houses and adobe walls surrounding vineyards near the city of Mendoza by Jörgensen (1909, 1912a), but, so far, there have been no detailed descriptions of the nests or damage caused by this nesting activity (Rolón \& Cilla 2010). The aims of this work were the macroscopic and microscopic studies of the nests and the stages involved in the process of nesting of C. muralis in the adobe walls of Capayán ruins and recent earthen constructions in Udpidango and Villa Castelli. In addition, we discuss the possible factors that may explain the high density of nests observed in the adobe walls of Capayán ruins by means the sustrate chosen for nesting and same aspects of the nesting habits: plant species visited for larval food resources. To date, these ruins have no adequate heritage protection. Capayán ruins constitute a settlement built in the historical Argentinean colonial period, in the late seventeenth century (De la Vega Díaz 1994). This settlement is composed by a group of historic earthen buildings and constitutes a highly valuable exponent of local architecture.

\section{Material and methods}

\section{Study site}

The ruins of Capayán and the recent earthen constructions where the nesting of Centris was studied are settled in the northern area of the Monte desert in the province of La Rioja, Argentina. The biogeographic province of Monte, ranging from $24^{\circ} 35^{\prime}$ to $44^{\circ} 2^{\prime} \mathrm{S}$ and from $62^{\circ} 54^{\prime}$ to $69^{\circ} 5^{\prime} \mathrm{W}$, is defined as a xeric biome according to its vegetation and physiognomy (Roig-Juñent et al. 2001). The climate is subtropical, warm temperate, with a mean annual temperature of $15^{\circ} \mathrm{C}$ and annual rainfalls ranging from 80 to $200 \mathrm{~mm}$. The drought intensity, duration and the season of the rains for separating two different climatic areas. The north Monte, from $37^{\circ} \mathrm{S}$ to the north, has summer rainfall concentration, while the southern Monte, south of $37^{\circ} \mathrm{S}$, no concentration of rain in the summer. These are usually torrential and have a temporal and spatial variability marked (Morello 1958; Cabrera 1976; Burgos 1963). The vegetation is uniform despite the enormous area occupied by the Province (Cabrera 1976). The province of Monte is presented in La Rioja in the wide valleys of north-south orientation, in the middle area of influence, and the lower slopes of the Cordillera it goes penetrating through the bottom of the ravines to 3100 $\mathrm{m}$ a.s.l., where interdigitate with the Prepuneña province. Physiognomically, the Monte is a mosaic of three vegetation types: the climax shrubland, halophyte shrub steppe soil and the forest which is a type azonal soil. The predominant climax vegetation is a scrubland; the characteristic endemic flora is represented mainly by the family Zygophyllaceae, Larrea, Bulnesia, and Plectocarpa genus. The dominant community is the "jarillal", an association of three species of Larrea ("jarilla" or creosote bush), Larrea divaricata or Larrea cuneifolia, accompanied by Larrea nitida, Monttea aphylla ("matasebo"), Bougainvillea spinosa 
("monte negro"), Senna aphylla ("pichana"), Cercidium praecox ("chañar brea"), Chuquiraga spp. ("chilladora"), Bulnesia retama ("retamo") and Lycium spp., the herbaceous layer is dominated by Trichloris crinita, Pappophorum caespitosum, Aristida mendocina, and some succulents and annuals. The halophyte shrub steppe consists of species such as Suaeda divaricata, Atriplex spp, Alleronfea vaginata. The forest of Prosopis spp, known as "algarrobal" appears only in places with an extra supply of water, and has a tree stratum very open dominated by Prosopis flexuosa var. depressa ("alpataco") or P. chilensis ("algarrobo chileno"), accompanied by Geoffroea decorticans ("chañar"). The shrub stratum is dominated by Capparis atamisquea ("atamisque") and species of the genus Larrea (Morello 1958; Cabrera 1976). The flowering was restricted to Spring-Summer months (September to April). Some species, such as Larrea divaricata and Bulnesia retama, which are predominant in this arid ecosystem, present two blooming periods (Michelette \& Camargo 2000). The initial blooming peak occurs in early spring, following a normally rainless cold winter. In September and October, only Zygophyllaceae species were flowering (Larrea divaricata, Larrea cuniefolia, Bulnesia retama). The summer rains also induce a resurgence of flowering, but the level of flower production in $L$. divaricata is considerably lower than in the spring. The bee community is structured in distinct seasonal cycles associated with the different plant blooming periods.

The ruins of Capayán are located in the department of Famatina (La Rioja, north-western Argentina, $29^{\circ} 03^{\prime} \mathrm{S}$, $\left.67^{\circ} 26^{\prime} \mathrm{W}\right), 10 \mathrm{~km}$ from Chilecito, at $1033 \mathrm{~m}$ a.s.l. Six samples of approximately $2.5 \mathrm{~kg}$ (about $10 \times 10 \times 15 \mathrm{~cm}$ ) were taken from detached material consisting of three pieces of brick with and without nests. The bee activity was observed and photographed in earthen walls of recent houses in Udpinango (interior valley of Velasco, La Rioja, $28^{\circ} 41^{\prime} \mathrm{S}$, $66^{\circ} 48^{\prime} \mathrm{W}$ ). Wall samples with an early step of biodeterioration (intact plaster) were taken from adobe walls of houses in Villa Castelli (Bermejo river valley, La Rioja, $29^{\circ} 03^{\prime} \mathrm{S}$, $\left.68^{\circ} 15^{\prime} \mathrm{W}\right)$. Samples were taken from intact plaster consisting of three pieces (about $10 \times 10 \times 2.5 \mathrm{~cm}$ ) containing the holes used as nest entrances.

\section{Nest analyses}

The pattern, density and orientation of the nests in the adobe samples were first determined. Some cell cavities $(20$ 25 each sample) were then cleaned to measure the length and width of the cells. The removed sediments were examined to determine the residual harvested pollen and fecal deposits. Non-emerged adults and larvae were used for taxonomic identification. Then, walls of the clean cell cavities were tested with a drop of water, and a piece of adobe sample containing portions of cell walls was placed in water for $24 \mathrm{~h}$ to test the water retardant nature and resistance of the cell walls material.

\section{Ultrastructural analyses}

Samples from bricks with and without nests were impregnated with Araldite epoxy resin (Distraltec, Buenos Aires). Then, thin sections were prepared according to the technique described by Jongerius \& Heintzberger (1975), mounted and observed under a light microscope. Parts of cell walls with and without remaining cocoons and lining were dried at $80^{\circ} \mathrm{C}$ overnight. Small pieces were then taken with a Vshaped-end microspatula, gold-coated and mounted for examination under a scanning electron microscope (SEM EDS, Inca Energy, Oxford Instruments scanning electron microscope with field emission gun [FEG] Zeiss DSM 982 Gemini secondary electron in-lens detector).

\section{Palynological analysis}

Palynological analysis of samples from cell contents was used to determine the foraging habits of $C$. muralis. The cell contents, consisted in the removal sediments from 65 cells cavities cleaned for measurement, were treated with potassium hydroxide solution (HOK) in a double boiler. The advantages of the HOK method are its simplicity and deflocculating effects, which allow to successfully separate the pollen adhered to cell sediments (Caccavari \& Cilla 2010). An aliquot $(1 / 3)$ of the polliniferous material was mounted in glycerin on a slide and stained with fuchsin, and total pollen was counted. For the taxonomic recognition, a pollen reference collection of plant specimens collected around the study area was used after preparing it with the technique described above. Each reference slide was supported by the corresponding specimens deposited in the herbarium "Gaspar Xuarex" of the Facultad de Agronomía of the Universidad de Buenos Aires (BAA), Argentina.

\section{Results}

\section{Adobe wall characterization}

Our studies showed that the earthen walls at Capayán were built using adobe sun-baked bricks of $10 \times 20 \times$ $40 \mathrm{~cm}$ that were bound to each other using earthen mortar joints $3 \mathrm{~cm}$ thick. The walls were plastered on both surfaces with earthen mortar $2 \mathrm{~cm}$ thick. The wall selected for study consisted of 28 adobe courses resulting in a $40 \mathrm{~cm}$ thick and $325 \mathrm{~cm}$ high wall. The high density of nests was observed in the face of the wall corresponding to the exterior of the building. The eroded zones exhibited high density of cavities on the surface as a result of removal of the cells ( 708 cavities $\mathrm{m}^{-2}$, SD $<5 \%$ ), which resulted in $9.38 \mathrm{~kg}$ of material removed by bee activity (Fig. 1). Erosion in the attacked parts reduced the thickness of the adobe wall to ca. $7 \mathrm{~cm}$ compared to parts without nests. Upon comparing cavity densities between adobe and joints, we observed that the percentage of cells was higher $(30 \%)$ in joints than in adobe. Interestingly, we found that the eleven lower adobe courses did not exhibit the cavities observed in all the upper courses.

\section{Nest characterization}

No new nests are being constructed or provisioned in Capayán ruins, data presented about this site refer only indirectly to nesting. The nest cells, usually vertical $\left(10^{\circ}\right.$ with respect to the vertical axes) to slanting $\left(75^{\circ}\right.$ with respect to the vertical axes) (Fig. 2), were found mainly within the first $12 \mathrm{~cm}$ of the adobe walls of the ruins. The cells were elongate, oval, with rounded bottom, roughly symmetrical around their long axes. Nests were distributed covering the whole surface of the adobe wall (except the eleven lower adobe courses) where could distinguish patches with the highest density of nests that other. In zones that exhibited lower density of nests, it was possible to study the cell arrangement. Bees completed a nest with one cell. In some cases, two cells defining a linear series pattern were 

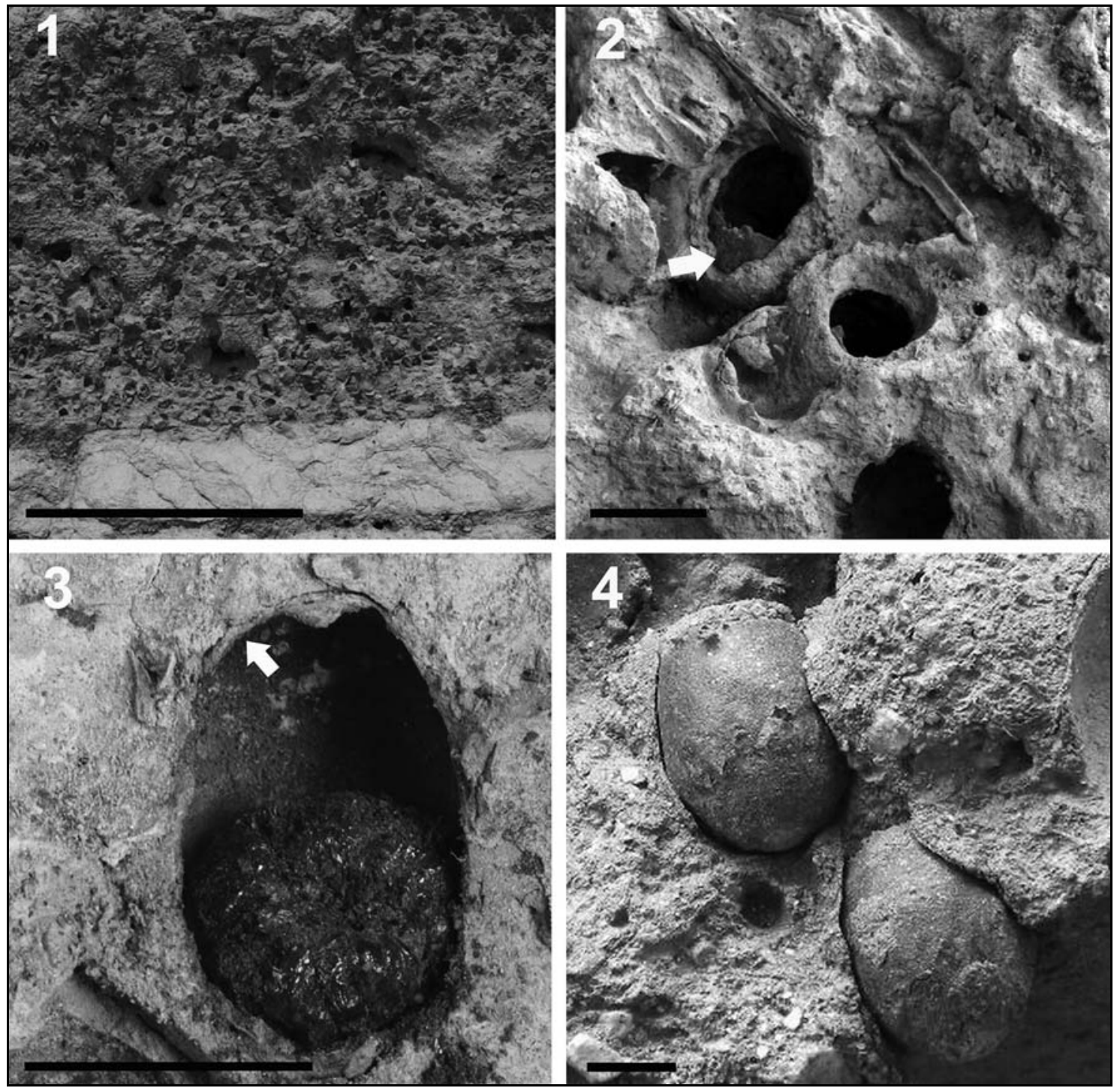

Figs 1-4. Nests and detail of the cell nest of Centris muralis inserted into the adobe walls of Capayán ruins, La Rioja, Argentina: 1 Eroded zones exhibited high density of voids as a result of cells cavities; 2 - The cells and the cell walls exhibited thick layer of hard material (arrow); 3 - The thick layer of the cell walls (arrow) and the Centris muralis larva found within the cell; 4 - The cocoons. Scales $10 \mathrm{~cm}$ (Fig. 1), $1 \mathrm{~cm}$ (Fig. 2, $1.5 \mathrm{~cm}$ (Figs 3, 4).

present. Non-emerged adults and larvae with varying states of development found within the cells (Fig. 3) were identified as $C$. muralis.

The cells were separable from the substrate with much difficulty and not completely. The cavities of the cleaned cells $(n=25)$ were $20-22 \mathrm{~mm}$ in length and $12-14 \mathrm{~mm}$ in maximum diameter. The necks of the cells were $8-9 \mathrm{~mm}$ wide. The cell walls were harder than the adobe even where the substrate was comparatively firm. The cell walls were approximately $0.7 \mathrm{~mm}$ thick, consisting of a hard material made of compacted soil particles probably cemented with a hardening substance and apparently waterproofed (Figs 2 and 3, indicated by arrows). The cell wall material, when the inner surface was tested with a drop of water, was water-retardant and the cell walls did not crumble when submerged in water. The bottom of the cells was weaker than the walls. The inner surface of the cell was smooth and lined with a thin, semitransparent, shiny, waxy mate- rial on the entire surface. The waxy material could be peeled off the cell surface completely only from the cell caps, whereas in the remaining areas it could not be removed completely. The lining remained intact as a thin film when the cell walls were submerged in water. This material was clearly distinguishable in those cells where the larvae died before spinning the cocoon (Fig. 3); after cocoon construction the shine of the wax tended to dull. The brownish cocoon consisted of a thin and multilayer structure (Fig. 4). The cocoon was semitransparent and the outer surface was adhered to the wax-like cell lining. The cocoon, with the waxy material adhered to it, could be removed completely from the cell surface. The cells were closed by caps made of material which resembled that of the cell walls, except that the waxy material presented a some what lighter color. Their outer surface bore a central low mound corresponding to a pit on the inner surface. Because of the degree of erosion, we were not able to see whether 

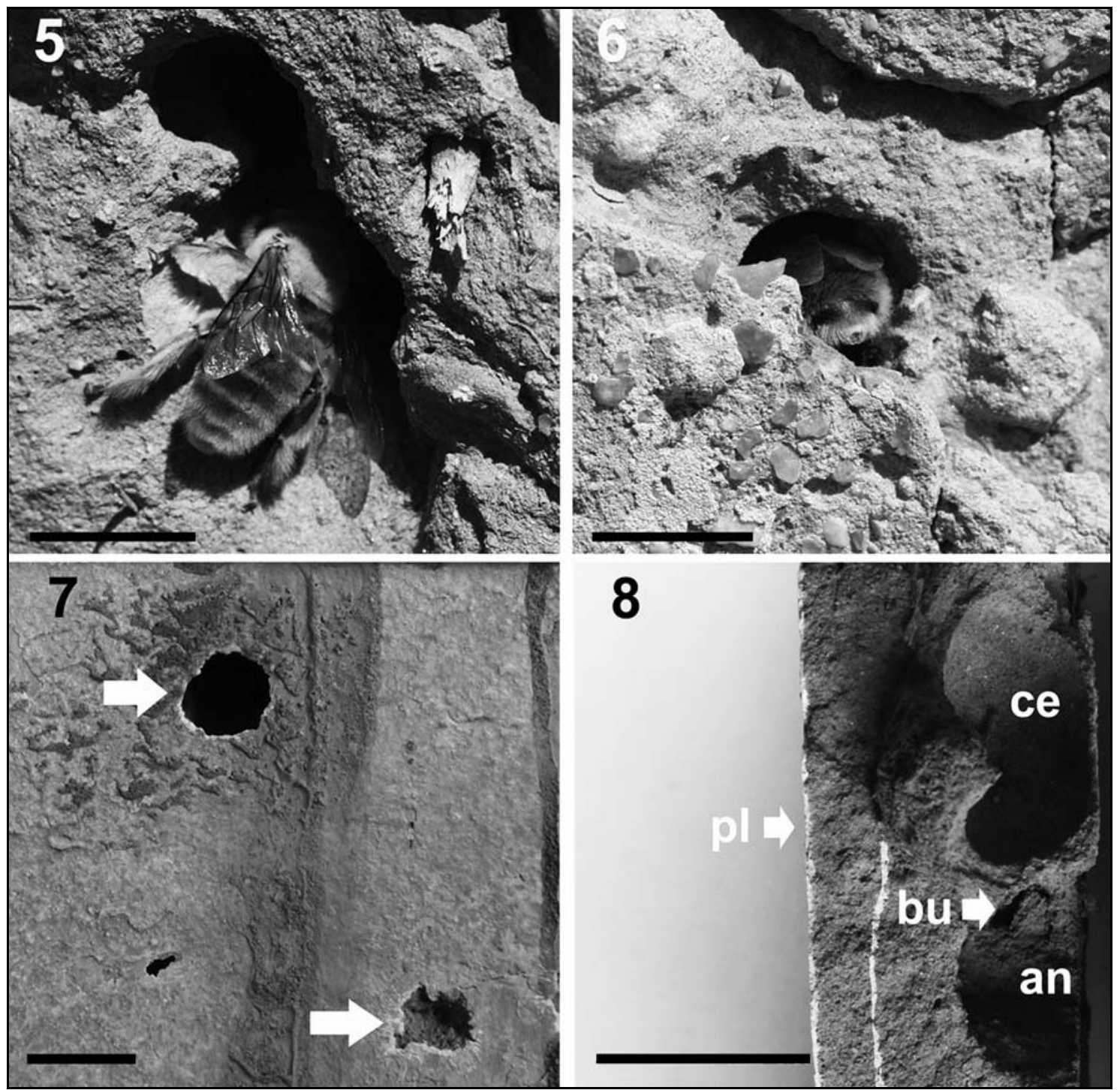

Figs 5-8. Nesting behavior of female in abandoned adobe walls (Figs 5, 6) (Udpinango, La Rioja) and wall with early signs of Centris muralis nesting (Figs 7,8) (Villa Castelli, La Rioja): 5 - Female used the preexistent hole in the adobe wall as entrance to the nests; 6 - Female drilled through the adobe brick with the mandibles while removing loose material with the legs; 7 - Holes practices with the female mandibles in the intact plaster, the final diameter was $9 \mathrm{~mm} ; 8$-Superficial nest consisted in a cell (ce) located below the reverse of the plaster $(\mathrm{pl})$ and the burrow (bu) expanded into a antechamber (an) immediately above the cell (indicated whit arrow the connection with the burrows). Scales $1.5 \mathrm{~cm}$ (Figs 5, 6), $1 \mathrm{~cm}$ (Figs 7,8).

this structure possessed a passageway connecting the cell chamber with the burrow. In some cases, the cells presented a small hole in the cap. The inner depression did not present the fine radial streaks formed by the bee tongue during cell closure, observed in other Centris species (Batra \& Schuster 1977).

The cells were found to be reoccupied by other specimens of $C$. muralis. Some cells contained a double multilayer structure corresponding to the brownish cocoon of $C$. muralis. One of the cells contained another cell with an adult female of the megachilid bee Epanthidium aff. sanguineum (Friese, 1908). Another eight cells within the cavity contained similar cells (10$12 \mathrm{~mm}$ in length, and $6 \mathrm{~mm}$ in diameter), probably of the same megachilid species. The megachilid nest cells presented a thin mud outer layer $(1.0-2.5 \mathrm{~mm})$ and a thick fibrous (plant tissues) inner layer (1.0-2.0 mm). Surprisingly, when the material of this fibrous layer was milled with the fingers, it was possible to recognize the characteristic odor of Larrea (jarilla) at blossom time.

Because of the degree of erosion, many of the cells studied in Capayán ruins were exposed on the surface of the wall and thus the burrows entrance to the nests could not be studied. The nesting activity was observed in the adobe walls of recent houses in Udpinango. Several females of $C$. muralis used the same hole in the adobe wall as entrance to the nests (Fig. 5). One female drilled through the adobe with the mandibles while removing loose material with the legs (Fig. 6). In Villa Castelli some females drilled through the intact plaster with the mandibles. The final diameters of the holes were $9 \mathrm{~mm}$ (Fig. 7). The samples collected in Villa Castelli, pieces with early step of biodeterioration containing the holes, showed the superficial nest consisting of a cell located behind the reverse of the plaster (Fig. 8). Immediately above the cell, the burrow ex- 

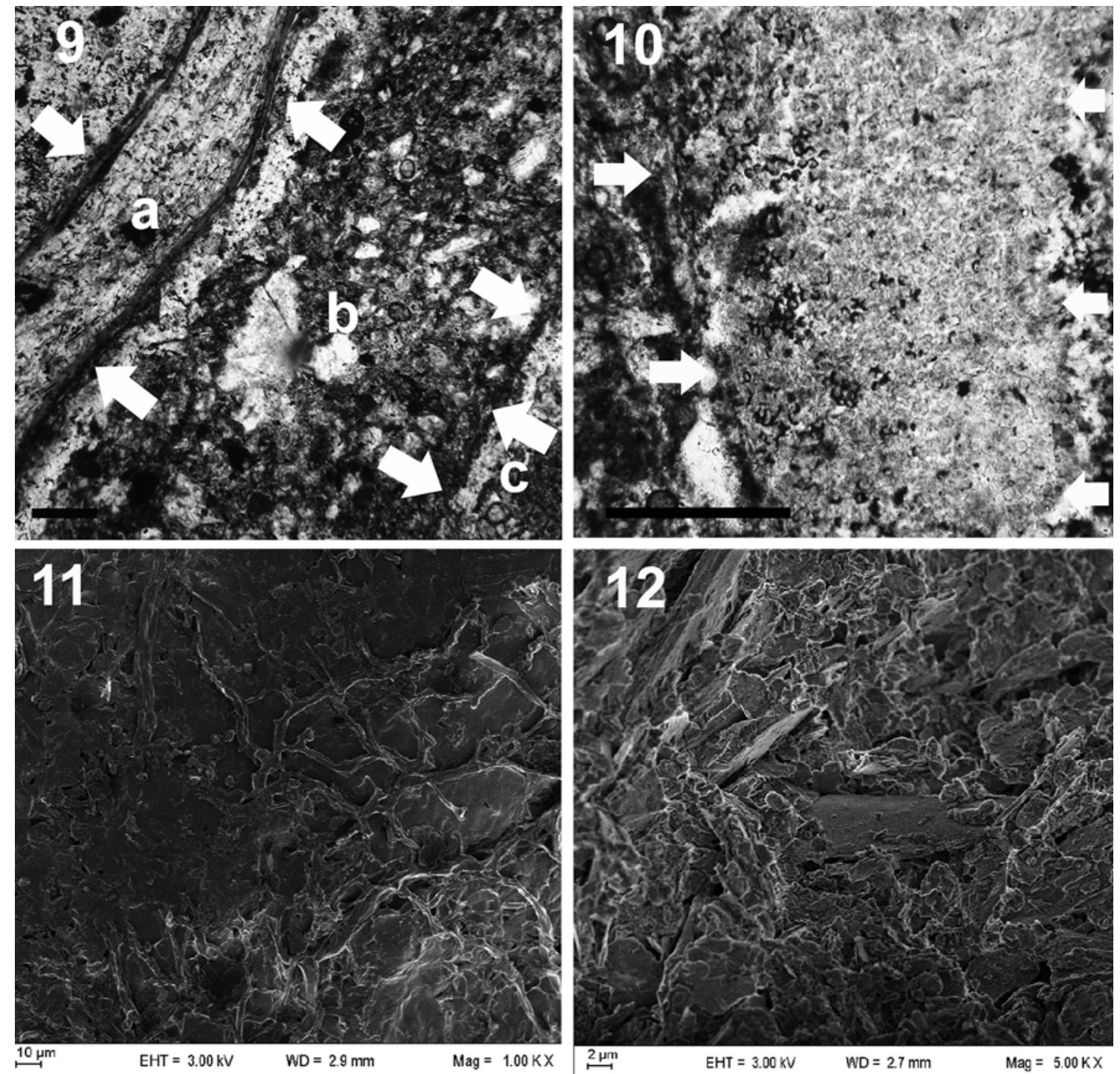

$\stackrel{2 \mu m}{\Perp m}$

$\mathrm{EHT}=3.00 \mathrm{KV}$

WD $=2.7 \mathrm{~mm}$

Mag $=5.00 \mathrm{KX}$

Figs 9-12. Light micrographs of the vacated cell walls (Figs 9, 10) and scanning electron micrographs (SEM) of the cell walls (Figs 11, 12) of Centris muralis nest: 9 - Thin sections of cell walls exhibited the inner layers of organic material corresponding to the cocoon and the wax like cell lining adhered to it (a) and the outer layer of $0.7 \mathrm{~mm}$ thick consisting mainly of silt and clay, fine sand grains in low rate and absence of grains of sand medium and large (b), beyond the thick layer there is no material alteration due to nesting activity (c); 10 - Thin sections of cell walls showed the pollen deposits (indicated by arrows); 11 - The cocoon layers covered the cell walls by a lax net; $12-$ The cell walls exhibited abundant clay crystals. Scales $0.01 \mathrm{~cm}$ (Figs 9,10$)$.

panded into a chamber $15.6 \mathrm{~mm}$ in length and $11 \mathrm{~mm}$ in diameter (Fig. 8, arrow indicates the connection with the burrows). The burrow and antechamber were unlined and rough, and showed the same consistency as the substrate. The antechambers were not observed in the nests of Capayán ruins walls.

\section{Light micrograph analysis}

Thin sections of vacated cells in biodeteriorated adobe brick samples, mounted and observed by light microscopy, exhibited two layers. The inner layer of brownish organic material, which showed a thin and multilayer structure, corresponded to the cocoon (a, Fig. 9); the waxy material was indistinguishable. The outer layer, of approximately $0.7 \mathrm{~mm}$ thick, corresponded to the cell wall. It consisted mainly of silt and clay, and also fine sand grains but without medium or large sand grains (a, Fig. 9). Silt and clay crystal were adhered to each other by a non-substrate type of cementitious material which was probably secreted by the bee. Beyond the outer layer there was no material alteration due to the nesting activity (c, Fig. 9), presenting the adobe matrix medium and large sand grains. Micrographs of those cells where the larvae had died before spinning showed pollen deposition at the bottom of the cells (Fig. 10, indicated by arrows).

\section{Scanning electron micrographs (SEM)}

Figure 11 illustrates the inner layer composed of a lax net upon a smooth and continuous surface without clay crystals. This surface corresponds to the inner face of the cell wall. The cell walls and non-nesting zones exhibited abundant clay crystals in the grain distribution (Fig. 12). 

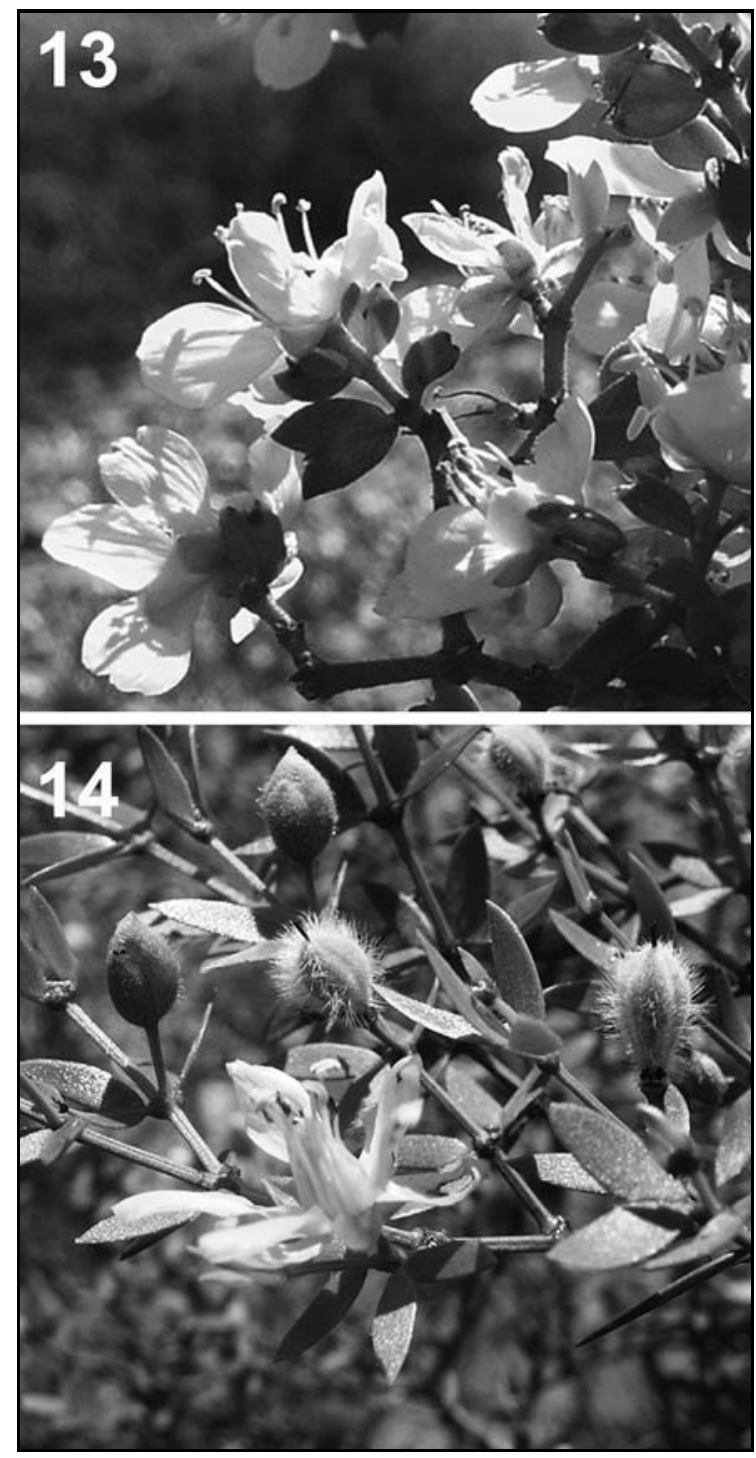

Figs 13, 14. The major source of wildflowers on which local apifauna feed after the summer rainstorms: 13 - The flowering mass in L. cuneifolia; 14 - The scarce flowering in L. divaricata.

Table 1. Number of samples, and percentage of pollen in each sample, of plant taxa present in cell contents of Centris muralis.

\begin{tabular}{lllll}
\hline \multirow{2}{*}{ Taxa } & \multicolumn{2}{c}{ Number of cells of } & Centris muralis \\
\cline { 2 - 5 } & $<5 \%$ & $5-50 \%$ & $>50 \%$ & $100 \%$ \\
\hline $\begin{array}{c}\text { Euphorbiaceae } \\
\text { Acalypha sp. }\end{array}$ & 6 & & & \\
$\begin{array}{c}\text { Zygophyllaceae } \\
\text { Bulnesia retama } \\
\text { Larrea cuneifolia } \\
\text { Larrea divaricata } \\
\text { Unidentified }\end{array}$ & 3 & & 18 & 9 \\
\hline
\end{tabular}

\section{Palynological analyses}

Pollen from Larrea sp. was observed mixed with sediments in the 65 cell contents analyzed. However, only 27 samples of cell sediments examined contained a rep- resentative amount of pollen grains (Table 1$)$. Nine cells contained only pollen from Larrea cuneifolia (100\%) (Fig. 13). The remaining 18 cells had varying proportions of at least five types of pollen: L. cuneifolia (70\%), L. divaricata (26\%) (Fig. 14), and other minor pollen source species, the unidentified pollen grains, Acalypha sp. and Bulnesia retama (4\%). Several unidentified spores were also found in the cell contents mixed with sediments.

\section{Discussion}

The reports of Jörgensen (1909) describe the nest cells and burrows of $C$. muralis. In the present work, the cavities of the cleaned cells were 5 to $3 \mathrm{~mm}$ smaller than the cells observed by Jörgensen ( $25 \mathrm{~mm}$ long and $18 \mathrm{~mm}$ wide). These differences could be due to the size polymorphism present in $C$. muralis specimens. Jörgensen reported that the burrows were 25.4 to $76.2 \mathrm{~mm}$ in length. This author did not observe the antechamber immediately above the cells present in samples with early nesting signs in Villa Castelli adobe walls. A similar antechamber was observed in C. pallida by Rozen \& Buchmann (1990). These authors hypothesized that the burrow enlargements allow the female to construct, provide, and close the cells. In the eroded walls of Capayán ruins, the nests did not exhibit the antechamber, probably because the females used the old cells, present in high density in the walls, like an antechamber and burrows entrance. In contrast with that observed in most Centridini, some nests of $C$. muralis contained two cells, in a linear series pattern (Fig. 4). Janvier (1955, in adobe walls in Cochabamba, Perú) described the nest of $C$. autrani with a similar linear series pattern, but the number of cells was greater, six to eight cells per nest, in comparison with that found for $C$. muralis.

The cell walls could be constructed by compacted particles adhered among them by organic cementitious material deposited by the bee. The nature of this hardening waterproofing substance is unknown in $C . m u$ ralis. The recorded plant hosts from the observation of flower visits (Jörgensen 1909; Neff \& Simpson 1981) and structural differences in the basitarsal combs, from those of species known to collect oils, suggest the probable loss of oil collecting habits in this species (Neff \& Simpson 1981). Other Centris species, that lost the habit of collecting oil, compacted soil particles presumably by a secretion of the bee (Chiappa \& Toro 1994; Rozen \& Buchmann 1990). Most bee species (including Centris, see Cane \& Brooks 1983), secreting different Dufour's gland lipids which are used to waterproof their brood cells (Cane 1981; Batra 1984; Cane \& Carlson 1984; Hefetz 1987). This is evidenced by correlation of glandular enlargement with nesting activity. Probably, Centris muralis build its nest cells with compacted soil particles that are not waterproofed with oils, lined with a thin, shiny hardening substance secreted. This condition parallels that of $C$. mixta and C. pallida, species of North and South American deserts that loss the oilcollecting habits. The fact that the oil-collecting habit 
has been lost in species of Centris in the most xeric environments suggest that the advantages of oil collecting may be related to the possible role of oils in controlling hygroscopic effects on the pollen provisions among bees nesting in humid environments (Neff \& Simpson 1981). In other Centris bee cells, Vesey-Fitz Gerald (1939) noted that the lining wax-like substance initially liquid penetrated between the dirt particles while it was hardening. In C. muralis this idea was reinforced after observing that SEM photographs exhibited a smooth surface and total lack of clay crystals (Fig. 11). Nevertheless, the light micrographs showed that the granulometry of the cell walls is very similar to that of the adobe brick, thus suggesting that the disappearance of adobe particles in the SEM photographs may be due for the addition of bee secretions to the adobe matrix.

A similar depression to that observed in the $C$. muralis cap cell closure was noted by Janvier (1926) in other species of Centris, C. cineraria Smith, 1854, and C. nigerrima (Spinola, 1851), nesting in adobe walls in Santiago de Chile, Chile. In $C$. transversa the caps had an eccentric depression with fine radiating streaks formed by the bee tongue during cell closure (Batra \& Schuster 1977). In C. muralis, the cap depressions were centric without fine radiating streaks. Because of the degree of erosion in the walls of Capayán ruins, it was not possible to observe if the closure of cells possessed a passageway connecting with the burrow. In some cases, the cells presented a small hole in the cap, but this was not a determining factor to confirm that the closure of C. muralis bears a spout-like opening. This structure, characteristic in some other Centris (Rozen \& Buchmann 1990), is absent in the closure of C. pallida nest cells (Alcock et al. 1976) and the gas exchange is apparently possible through the not-waterproof cell closure. In $C$. muralis the cell closure seemed to be constructed of the same waterproofed material as the cell walls. Because gas exchange is apparently impossible through a waterproofed, closed cell, how gases are exchanged in the cells of $C$. muralis remains to be clarified. Noteworthy is the fact that $C$. muralis presents similarities in cell nest structure and non-oil-collecting habits to the superficially quite similar C. pallida.

Two factors should have been crucial for the rise of Capayán ruins walls as the preferred suitable nesting habitat for $C$. muralis: the availability of forage in close proximity to the nests and the large homogeneous surface, which structure created a habitat that was attractive as nesting site. Several Centris species have been described as polylectic (Aguiar et al. 2003; Dorea MC et al. 2010). However, previous report suggested that C. muralis was active only during the spring bloom of Zygophyllaceae, visited preferentially flowers of $L$. $d i$ varicata and B. retama (Michelette \& Camargo 2000). Pollen from Larrea sp. was observed in high proportions in the nest contents of $C$. muralis in the Capayán adobe walls. The dominance of Larrea in desert scrub areas make it a major source of wildflowers on which local apifauna feed. Species of Larrea are opportunistic bloomers and, probably, the signals used to initi- ate a bloom also used as emergency signal by many of its flower visitors. Their reproductive systems and flower-insect associations have been studied in detailed for Simpson et al. (1977) near the city of Andalgalá, Catamarca, in the northern Monte of Argentina. In this region, the summer rains are heavy and extensive and comprise most of the annual precipitation. These summer rains trigger the mass flowering of L. cuneifolia, in facultative response to moisture availability. Typically, L. cuneifolia bloom in short and intense bursts following the summer rainstorms (Fig. 13), often less than a week on the flats, to extending in microhabitats where the water accumulates. Scattered individuals occurring in more mesic habitats with $L$. divaricata bloom continuously to several months (October until February or March), with only a few flowers per shrub. The summer rains also induce a resurgence of flowering in $L$. divaricata, but the level of flower production is considerably lower than in the spring (Fig. 14). Larrea divaricata has an initial blooming peak in early spring (October), following a normally rainless cold winter. Individuals may continue to blooming, usually at a low level, for a prolonged period in relatively mesic wash and upper bajadas. In these areas $L$. cuneifolia and $L$. divaricata do occasionally occur and flower together the bees visit both species. Bees foraging under this condition tend to be concentrated on the individuals having the greatest concentration of fresh flowers regardless of the plant species. The high proportions of the pollen of $L$. cuneifolia in the brood cells of $C$. muralis (Table 1 ) could be due to the dominance of this species of jarilla in the area where the Capayán ruins are settled, or to the fact that the cues used to initiate blooming are also used as emergence cues by $C$. muralis. However, these results represent only a relatively small number of nests sampled. Studies at different times of the nesting season, and different nesting sites on a wide geographic range, are needed to determine the pollen preferences and bee activity of $C$. muralis.

Besides pollen and nectar, species of Larrea offer other natural products (waxes, volatiles, saponins and specially phenolics) (Mabry 1977). The nest cells of Epanthidium aff. sanguineum, built into the old cells of $C$. muralis, smelled as Larrea spp. Fields observations indicate that this generalist megachilid bee visits jarilla species (Simpson et al. 1977). Probably, Epanthidium aff. sanguineum collected waxes or the other natural products of Larrea to embed the plant fibers for building the single cell per nests (Michener 2007).

The results of this work led us to propose a model for the various stages involved in the process of nesting in adobe walls. Initially, $C$. muralis makes small holes (Fig. 7). These holes are used by several individuals as an entrance within the wall for the construction of cells. The first nests are constructed within the wall, but close to the surface, behind the plaster (Figs 8 and 15). A second stage occurs when the presence of a significant number of cells (Fig. 16) weakens the plaster and the wall and causes the release of the first (Fig. 17). The action of bee nesting continues even in 

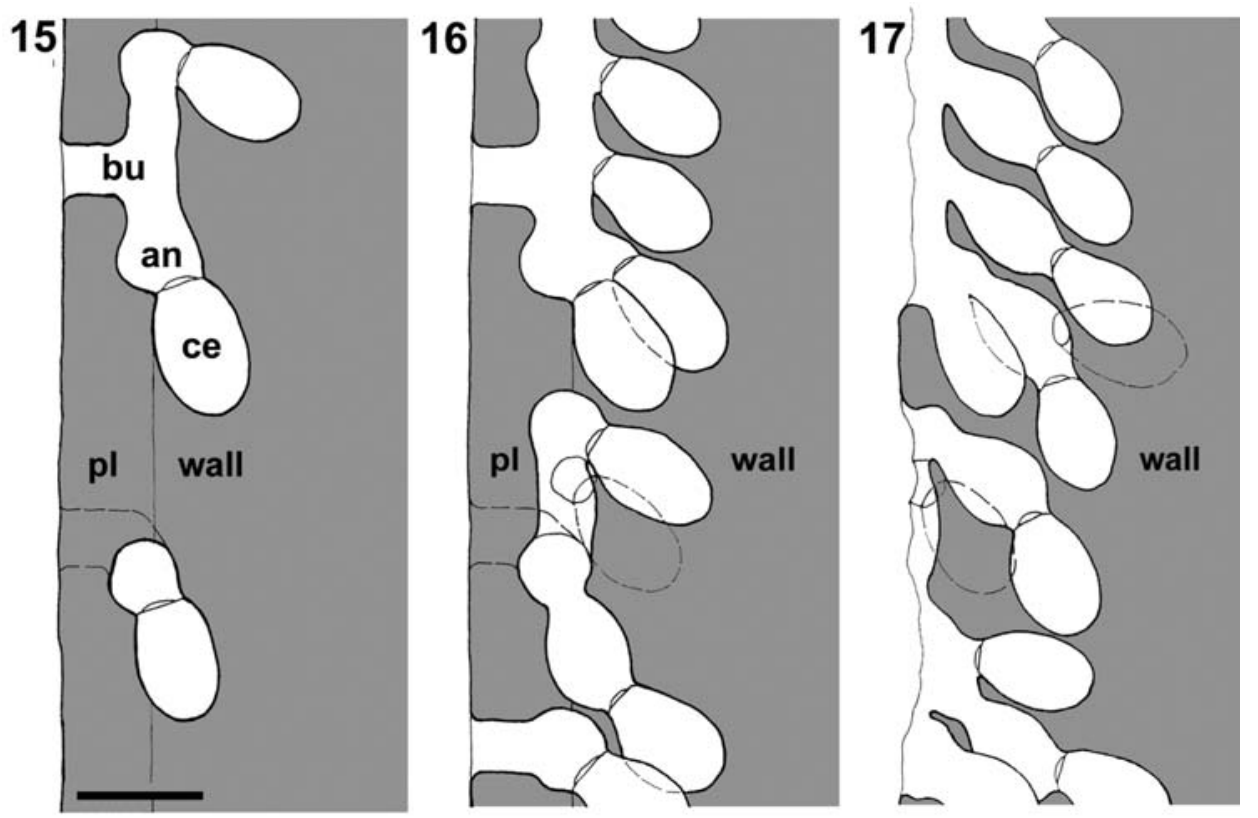

Figs 15-17. The model propose for the various stages involved in the process of Centris muralis nesting: 15 - C. muralis makes small holes in the intact plaster (pl) and the first nests are constructed, behind the plaster (superficial nest consisted in a cell (ce) and the burrow (bu) expanded into a antechamber (an)); 16 - The presence of a significant number of cells binding weakens the plaster and the wall and causes the release of the first; 17 - The action of bee nesting continued even in the absence of this protective layer looking to penetrate further into the wall. Scale $2 \mathrm{~cm}$.

the absence of this protective layer looking to penetrate further into the wall. Females take advantage of the preexisting holes in the wall surface (Fig. 5) or make small holes (Fig. 6). The erosive effect of $C$. muralis is twofold: (i) the bees actively remove $9.38 \mathrm{~kg}$ of material from adobes when digging burrows and cells to nest, exhibiting high density of cavities (708 per $\mathrm{m}^{-2}$, SD $<5 \%$ ) on the surface; (ii) the nests weaken the adobe structure and some parts collapse, erosion in the parts with nests thinned the adobe wall about $7 \mathrm{~cm}$ compared with parts without nests. Probably the effects of rain reinforce the mechanical action of nesting. As erosion progresses, many occupied cells become exposed on the surface of these walls. Since the number of cells in the Capayán ruins walls is high, we assumed that the bees reused the same site over the years. Old cells were apparently reoccupied by specimens of $C$. muralis, as well as by specimens of Epanthidium aff. sanguineum. Such nesting activity for constructing cells and burrows could cause serious damage by biodeterioration when the substrate chosen is a valuable historic site.

\section{Acknowledgements}

We thank to Leandro Papinutti of Facultad de Ciencias Exactas y Naturales, Universidad de Buenos Aires, Argentina, for valuable comments and discussion on this manuscript, Arturo Roig Alsina of Museo Argentino de Ciencias Naturales, Argentina, for identified the adults and valuable corrections, comments and suggestions, Victor H. Gonzalez Betancourt of Utah State University, United State, for your support in the bibliographic search, Gabriel H. Rua of Facultad de Agronomía, Universidad de Buenos Aires, Argentina, for the photography of two species of Larrea, and Instituto de Geocronología y Geología Isotópica, Argentina, staff and particularly Margarita Do Campo for the technical assistant.

\section{References}

Aguiar C.M.L. \& Gaglianone M.C. 2003. Nesting biology of Centris (Centris) aenea Lepeletier (Hymenoptera, Apidae, Centridini). Rev. Bras. Zool. 20 (4): 601-606. DOI: 10.1590/S0101-81752003000400006

Aguiar C.M.L. \& Garófalo C.A. 2004. Nesting biology of Centris (Hemisiella) tarsata Smith (Hymenoptera, Apidae, Centridini). Rev. Bras. Zool. 21 (3): 477-486. DOI: 10.1590/S010181752004000300009

Aguiar C.M.L., Zanella F.C.V., Martins C.F. \& Carvalho E.C. 2003. Plantas visitadas por Centris spp. (Hymenoptera; Apidae) na Caatinga para obtenção de recursos florais. Neotrop. Entomol. 32 (2): 247-259. DOI: 10.1590/S1519566X2003000200009

Alcock J., Jones C.E. \& Buchmann S.L. 1976. The nesting behavior of three species of Centris bees (Hymenoptera: Anthophoridae). J. Kansas Entomol. Soc. 49 (4): 469-474.

Batra S.W.T. 1984. Solitary bees. Sci. Am. 250: 86-93. DOI:10. 1038/scientificamerican0284-120

Batra S.W.T. \& Schuster J.C. 1977. Nest of Centris, Melissodes, and Colletes in Guatemala (Hymenoptera: Apoidea). Biotropica 9 (2): 135-138.

Burgos J.J. 1963. El clima de las regiones áridas en la República Argentina. Revista de Investigaciones Agrícolas. INTA 17 (4): $385-405$.

Burmeister H. 1876. Hymenopterologische Mittheilungen 1: Die Xylocopa-Arten des La Plata Gabinetes. Stett. Entomol. Zeit. 37 (1-3): 151-183.

Cabrera, A.L. 1976. Regiones fitogeográficas argentinas. En Kugler W.F. (ed.), Enciclopedia Argentina de Agricultura y Jardinería, Segunda edición, Tomo II Fs. 1, Ed. ACME. Bs. As. Argentina, 85 pp.

Caccavari M. \& Cilla G. 2010. Remoción química como nueva alternativa a la remoción mecánica para el estudio del polen transportado en las escopas de abejas silvestres. Rev. Mus. Argent. Cienc. Nat. 12 (2): 255-262. 
Camillo E., Garófalo C.A \& Serrano J.C. 1993. Hábitos de nidificação de Melitoma segmentaria, Centris collaris, Centris fuscata e Paratetrapedia gigantea (Hymenoptera, Anthophoridae). Rev. Bras. Entomol. 37 (1): 145-156.

Cane J.H .1981. Dufour's gland secretion in the cell linings of bees (Hymenoptera: Apoidea). J. Chem. Ecol. 7 (2): 403410. DOI: $10.1007 /$ BF00995762

Cane J.H. \& Brooks R.W. 1983. Dufour's gland lipids of three species of Centris bees (Hymenoptera: Apoidea, Anthophoridae). Comp. Biochem. Physiol. 76B (4): 895-897.

Cane J.H. \& Carlson R.G. 1984. Dufour's gland glycerides from Anthophora, Emphoropsis (Anthophoridae) and Megachile (Megachilidae) bees (Hymenoptera: Apoidea). Comp. Biochem. Phys. 78B (3): 769-772. DOI: 10.1016/0305-0491(84) 90132-9

Coville R.E., Frankie G.W. \& Vinson S.B. 1983. Nests of Centris segregata (Hymenoptera: Anthophoridae) with a review of the nesting habits of the genus. J. Kansas Entomol. Soc. 56 (2): 109-122.

da Costa Dórea M., Aguiar C.M.L., Figueroa L.E.R., Lima E., Lima L.C. \& de Assis R. dos Santos F. 2010. Pollen residues in nests of Centris tarsata Smith (Hymenoptera, Apidae, Centridini) in a tropical semiarid area in NE Brazil. Apidologie 42 (5): 557-567. DOI: 10.1051/apido/2010005

De La Vega Díaz D. 1994. Toponimia riojana. Editorial Canguro, La Rioja, Argentina, 333 pp. ISBN: 9879921682

Frankie G.W., Newstrom L.E., Vinson S.B. \& Barthell J.F.1993. Nesting habitat preferences of selected Centris bee species in Costa Rica dry forest. Biotropica 25 (3): 322-333. DOI: $10.2307 / 2388790$

Frankie G.W., Vinson S.B., Newstrom L.E. \& Barthell J.F. 1988. Nest site and habitat preferences of Centris bees in Costa Rican dry forest. Biotropica 20 (4): 301-310. DOI: $10.2307 / 2388320$

Frankie, G. W., Vinson, S. B. \& Opler P.A. 1983. Centris aethyctera and C. fuscata in the lowland dry forest of Costa Rica (Hymenoptera: Anthophoridae), pp. 707-708. In: Jansen D.H. (ed.), Costa Rica Natural History, University Chicago Press, 816 pp. ISBN: 0226393348, 9780226393346

Gaglianone M.C. 2001. Nidificação e forrageamento de Centris (Ptilotopus) scopipes Friese. [Nesting biology and foraging behavior of Centris (Ptilotopus) scopipes Friese (Hymenoptera, Apidae)] Rev. Bras. Zool. 18 (Supl. 1): 107-117. DOI: $10.1590 /$ S0101-81752001000500008

Hefetz A. 1987. The role of Dufour's gland secretions in bees. Physiol. Entomol. 12 (3): 243-253. DOI: 10.1111/j.13653032.1987.tb00749.x

Hiller B. \& Wittmann D. 1994. Seasonality, nesting biology and mating behavior of the oil-collecting bee Epicharis dejeanii (Anthophoridae, Centridini). Biocięncias 2: 107-124.

Hurd P.D. \& Linsley E.G.Jr. 1975. The principal Larrea bees of the southwestern United States. Smithson. Contrib. Zool.193: 1-74

Janvier H. 1926. Recherches biologique sur les hyménoptčres du Chili (Melliféres). Annales des Sciences Naturelles. Ann. Sci. Nat. Zool.9 (10): 113-268.

Janvier H. 1955. Le nid et la nidification chez quelques abeilles des Andes tropicales. Ann. Sci. Nat. Zool. 11 (18): 311-349.

Jesus B.M.V. \& Garófalo C.A. 2000. Nesting behaviour of Centris (Heterocentris) analis (Fabricius) in southeastern Brazil (Hymenoptera, Apidae, Centridini). Apidologie 31 (4): 503515. DOI: $10.1051 /$ apido:2000142

Jongerius A. \& Heintzberger G. 1975. Methods in soil micromorphology. A technique for the preparation of large thin secions. Soil Survey Papers 10. Netherlands Soil Survey Institute, Wageningen, $48 \mathrm{pp}$.

Jörgensen P. 1909. Beobachtungen über Blumenbesuch, Biologie, Verbreitung usw. der Bienen von Mendoza (Hym.). Deutsch. Entomol. Zeitschr. 54: 211-227.

Jörgensen P. 1912a. Revision der apiden der provinz Mendoza, República Argentina (Hym.). Zool. Jahrb. Abt. Allg. Syst. Öekol. Geogr. Tiere. 32: 89-162.

Jörgensen P. 1912b. Los crisididos y los himenopteros aculeados de la provincia de Mendoza. Anal. Mus. Nac. Bs. As. 22: 267-338.
Larson G. 1993. Charper 7: Animals, pp. 263-392. In: Kearns C.A. \& Inouye D.W. (eds), Techniques for Pollination Biologists, University Press of Colorado, Niwot, CO, 583 pp. ISBN-10: 0870812815, ISBN-13: 978-0870812811

Mabry T.J., DiFeo, D.R.Jr., Sakakibara M., Bohnstedt C.F.Jr. \& Seigler D. 1977. The Natural Products Chemistry of Larrea, pp. 115-284. In: Mabry T.J., Hunziker J.H., DiFeo Jr.D.R. (eds), Creosote Bush: Biology and Chemistry of Larrea in New World Deserts, Dowden, Hutchinson and Ross, Inc. Stroudsburg, PA, 304 pp. ISBN-10: 0879332824, ISBN-13: 978-0879332822

Mendes F.N. \& Ręgo M.M.C. 2007. Nidificação de Centris (Hemisiella) tarsata Smith (Hymenoptera, Apidae, Centridini) em ninhos-armadilha no Nordeste do Maranhão, Brasil. Rev. Bras. Entomol. 51 (3): 382-388. DOI: 10.1590/S008556262007000300017

Michelette E.R.F. \& Camargo J.M.F. 2000. Bee-plant community in a xeric ecosystem in Argentina. Rev. Bras. Zool. 18 (3): 651-665. DOI: 10.1590/S0101-81752000000300011

Michener C.D. 2007. The Bees of the World, 2nd Ed. Johns Hopkins University Press, New York, 972 pp. ISBN: 97808018857 300801885736

Michener C.D. \& Lange R.B. 1958. Observations on the ethology of neotropical anthophorine bees. Univ. Kans. Sci. Bull. 39 (3): 69-96.

Morello J. 1958. La Provincia Fitogeográfica del Monte. Opera Lilloana 2: 5-115.

Neff J.L. \& Simpson B.B. 1981. Oil-collecting structures in the Anthophoridae (Hymenoptera): Morphology, function, and use in systematics. J. Kansas Entomol. Soc. 54 (1): 95-123.

Quiroz-Garcia D.V., Martinez-Hernandez M., Palacios-Chavez R. \& Galindo-Miranda N.E. 2001. Nest provisions and pollen foraging in three species of solitary bees (Hymenoptera: Apidae) from Jalisco, Mexico. J. Kansas Entomol. Soc. 74 (2): 61-69.

Quiroz-Garcia D.V. \& Arreguin Sanchez M.L. 2006. Resource utilization by Centris flavofasciata Friese (Hymenoptera: Apidae) in Jalisco, Mexico. J. Kansas Entomol. Soc. 79 (3): 249-253.

Ramos M., Mendes F., Albuquerque P. \& Ręgo M. 2007. Nidificação e forrageamento de Centris (Ptilotopus) maranhensis Ducke (Hymenoptera, Apidae, Centridini). Rev. Bras. Zool. 24 (4): 1006-1010. DOI: 10.1590/S0101-81752007000400017

Ręgo M.M.C., de Albuquerque P.M.C., Ramos M.C. \& Carreira L.M. 2006. Aspectos da biologia de nidificação de Centris flavifrons (Friese) (Hymenoptera: Apidae, Centridini), um dos principais polinizadores do murici (Byrsonima crassifolia L. Kunth, Malpighiaceae), no Maranhão. Neotrop. Entomol. 35 (5): 579-587. DOI: 10.1590/S1519-566X2006000500003

Roig Alsina A. 2000. Clave para las especies argentinas de Centris (Hymenoptera: Apidae), con descripción de nuevas especies y notas sobre distribución. Rev. Mus. Argent. Cienc. Nat. 2 (2): 181-193.

Roig-Juñent S. \& Flores G.E. 2001. Historia geográfica de las áreas áridas de América del Sur Austral, pp. 257-266. In: Llorente Busquets J. \& Morrone J.J. (eds), Introducción a la biogeografía en Latinoamérica: teorías, conceptos, métodos y aplicaciones, Las prensas de Ciencias, Facultad de Ciencias, UNAM, México, Distrito Federal, 277 pp. ISBN: 968-36-94632

Rolón G. \& Cilla C. 2010. Studies of the biodeterioration caused by insects in a valuable historic colonial site in La Rioja province. Biocell. 34 (2): 104.

Rozen J.G. \& Buchmann S.L. 1990. Nesting biology and immature stages of the bees Centris caesalpiniae, C. pallida, and the cleptoparasite Ericrocis lata (Hymenoptera: Apoidea: Anthophoridae). Am. Mus. Novit. 2985: 1-30.

Roubik D.W. 1989. Ecology and natural history of tropical bees. Cambridge University Press, Cambridge, 514 pp. Online ISBN: 9780511574641 Hardback ISBN: 9780521262361 Paperback ISBN: 9780521429092

Sarzetti L.C. \& Genise J.F. 2011. Predation of Soil-Nesting Centris muralis (Insecta: Apidae) by Armadillos (Zaedyus pichiy) (Mammalia: Cingulata) in La Rioja Province, Northwestern Argentina. J. Kansas Entomol. Soc. 84 (3): 179-183. DOI: 10.2317/JKES100412.1 
Simpson B.B., Neff J.L. \& Moldenke A.R. 1977. Reproductive Systems of Larrea, pp. 92-114. In: DiFeo Jr. DR (ed.), Creosote Bush: Biology and Chemistry of Larrea in New World Deserts. Dowden, Hutchinson and Ross, Inc. Stroudsburg, PA. ISBN-10: 0879332824 ISBN-13: 978-0879332822

Snelling R.R. 1984. Studies on the taxonomy and distribution of American Centridini bees (Hymenoptera: Anthophoridae). Contrib. Sci. Nat. Hist. Mus. Los Angeles Co. 347, 69 pp.

Stange L.A.1983. A synopsis of the genus Epanthidium Moure with the description of a new species from northeastern Mexico. Pan-Pac Entomol. 59: 281-297.

Vesey-Fitz Gerald D. 1939. Observation on bees in Trinidad, B.W. I. Proc. R. Entomol. Soc. Lond. Ser. A Gen. Entomol. 14: 107-110 DOI: 10.1111/j.1365-3032.1939.tb00061.x
Vinson S.B., Frankie G.W. \& Cônsoli R. 2010. Description, comparison and identi $\beta$ ication of nests of cavity-nesting Centris bees (Hymenoptera: Apidae: Centridini) in Guanacaste Province, Costa Rica. J. Kans. Entomol. Soc. 83: 25-46. DOI: 10.2317/JKES0808.20.1

Vogel S. 1974. Olblumen und ölsammelnde Bienen. Franz Steiner Verlag GmbH, Wiesbaden, 267 pp. ISBN: 10: 3515019499

Zanella F.C.V. 2002. Sistemática, filogenia e distribuiçaõ geográfica das espécies sul-americanas de Centris (Paracentris) Moure, 1950, incluindo uma análise filogenética do "grupo Centris" sensu Ayala, 1998 (Hymenoptera, Apoidea, Centridini). Rev. Bras. Entomol. 46 (4): 435-488.

Received September 7, 2011 Accepted January 22, 2012 